\title{
Parity Effect on Camel Milk Composition under Traditional and Intensive Management Systems in Butana Area-Sudan
}

\author{
M. H. M. Elbashir ${ }^{1}$, Sijoud. F. Elhassan ${ }^{2}$, H. I. Abueissa ${ }^{3}$ \\ ${ }^{1,2}$ Tumbool Camel Research Center, Animal Resources Research Corporation, Khartoum, Sudan \\ ${ }^{3}$ Animal Production Research Center, Animal Resources Research Corporation, Khartoum, Sudan
}

\begin{abstract}
A total of 147 camel milk samples from healthy she-camels (Camelus dromedaries) in different (parity numbers (one to fifth), different breeds and seasons)were randomly collected to investigate the effect of parity on some chemical components of camels milkfrom intensive and traditional management systems in Butana area. Data obtained were analyzed with SPPS version 21 software using analysis of variance and independent-sample- T. Test. Results revealed that parity had significant effect $(P>0.05)$ on camel milk components that were collected from intensive management system. Wherein proteins, lactose, free fatty acid (FFA) and solid not fat $(S N F)$ were markedly affected by parity.Parity interaction effects showed significant differences $(P>0.05)$ between systems in values of protein, lactose, Fat, total solid contents and acidity during second parity up to successive parities. Primiparous seemed to have no significant effect $(P>0.05)$ on camel milk components that collected from the two management systems. The study concluded that parity had significant effect on some chemical components of camel milk under traditional and intensive management system.
\end{abstract}

Keywords: Camel, milk analysis, parity, system

\section{Introduction}

The milk composition of dairy animals has been widely studied throughout the world and thousands of references are available especially with regard to milk consumed by humans. The literature data mainly concerns cow milk, which represents $85 \%$ of the milk consumed in the world and, to a lesser extent, goat and sheep milk. Studies on other dairy animals like camel are rather scarce, inspite of their nutritional interest and medicinal properties. In addition, unlike other milk-producing animals, camels can thrive under extreme hostile conditions of temperature, drought, and lack of pasture, and still produce milk[35]. For that in this context, the effect of parity number on chemical composition of camel milk need to be further investigated.

\section{Materials and Methods}

\section{Study area:}

Camel milk samples obtained from the intensive system (Tumbool Camel Research Center) which located at the central part of Butan and traditional system system (open pastures of Butana area). The Butana plain is a semiarid clay mostly flat region. It covers most of the present Kassala and Gedaref States in Eastern Sudan. It is located between Latitude $1340^{\prime}$ and 17 50' North and Longitude 32 40' and 36 00' East. It is bounded by the Main River Nile on its northwestern border, the Blue Nile on its southwestern edge, the Atbara River in the northeast and by the railway connecting Kassala and Sennar in the south [3].

Vegetations:

Two vegetation zones are existing in the area, namely the semi desert Acacia shrub and short grasslands of North Central Sudan and the low woodland savannah of central Sudan. The vegetation of Butana is constantly changing as a result of annual rainfall, accidental fire outbreaks and expansion of agriculture and grazing, which depleted most of the highly palatable species such as BlepharisPersia (Elsiha) and Ipomoea cordofana (Eltabar)[31].Trees commonly found in the study area consist of Acacia mellifer (Kiter) as the most common tree, Acacia nubica (Loat) which indicates overgrazing areas and Acacia nilotica (Sunut). Grasses that dominate in the area are Cymbogon nervatus (Nal) which is fairly a non palatable grass, Aristidia Funicunlata (Gaw), Impomoea cardisepala (Hantot), Ipomoea cordofana (Taber) and Blepharispersica (Siha),which are good forage plants with high protein contents. The latter two species are becoming less abundant in recent years [1].

Concentrate rations used in intensive system at Tumbool Camel Research Center (TCRC):

The concentrate ration was formulated based on sugar cane by-products (molasses \& bagasse) and urea salt in maximal of $2 \%$. Crushed sorghum grain, ground nut cake and wheat bran were added at low percent (5-15\%), in addition to lick mineral stone, normal salt $(1.5 \%)$ and bicarbonates (1-2\%). The metabolizable energy (ME) and were kept around 9.2 MJ and 11-13\% respectively on dry matter-bases. The meal was given twice a day. The animals were grouped fed (lactating, pregnant, growers and mature bulls). These allowances were at the rate of 56-58 \% out of the total daily feed intake. The basic grass fodders were Abu-70 (Sorghum bicolor), Pioneer (Sorghum bicolor $x$ Sorghum sudanense hybrid), Clitoria (Clitoria ternate) and Berseem (Medicago sativa).

Collection of camel milk samples:

A total of 147 camel milk samples from 147 healthy shecamels were collected from intensive and traditional management systems in Butana area. One sample of $50 \mathrm{ml}$ from each she-camels (147) was taken (with different systems, seasons and parity numbers). The raw camel milk samples were collected in the early morning and

\section{Volume 6 Issue 12, December 2017}




\section{International Journal of Science and Research (IJSR) \\ ISSN (Online): 2319-7064 \\ Index Copernicus Value (2016): 79.57 | Impact Factor (2015): 6.391}

immediately labeled, stored in an ice box and transferred within 2-3 hours to the laboratory of the Department of laboratory, the samples were stored in freezer $\left(-20^{\circ} \mathrm{C}\right)$ until they were analyzed.

\section{Chemical composition of camel milk}

Chemical component of milk as percentages of fat, protein, solids not fat, total solids, lactose content and density, were measured twice using Lactoscan milk Analyzer (Milkotronic LTD, Europe) according to the manufacturer's instructions [19]. The analysis of milk was conducted at Dal Dairy Factory (DDF), Khartoum-North, Sudan[12]. Twenty five $\mathrm{ml}$ of the samples were taken in the sample holder after mixed gently 4- 5 times. The sample holder was put in the analyzer in the recess position and the analyzer sucks the milk and makes the measurement. When the measurement is finished, the sample returns in the sample holder and the digital indicator shows the specified result.

\section{Statistical analysis}

Different statistical tools were employed based on the available data obtained such as simple descriptive statistics,
Dairy Production, Tumbool Camel Research Center. At the

analysis of variance and independent-sample- T. Test. The computer software Excel was used for data managing and most of the data were analyzed with SPPS version 21 software.

\section{Results and Discussion}

\section{Camel milk components of intensive system (\%) as influenced by parity}

Parity had no effect $(\mathrm{P}>0.05)$ on camel milk components that were collected from intensive management system (Table 1). This may be attributed to sufficient nutrient supplementation and limitation of animal health care in intensive system as reported by [32]. Titratable acidity in primiparous and $5^{\text {th }}$ parity recorded highly significant differences $(\mathrm{P}<0.01)$ in comparison to milk from camels in the other parities. No explanation was found for this result.

Table 1: Camel milk components of intensive system (\%) as influenced by parity

\begin{tabular}{|c|c|c|c|c|c|c|c|}
\hline Parity Number & Fats & Proteins & Lactose & FFA & SNF & TS & Acidity \\
\hline 1 & $3.33 \pm 1.2$ & $2.89 \pm 0.8$ & $4.85 \pm 0.7$ & $1.03 \pm 0.3$ & $8.49 \pm 1.5$ & $12.3 \pm 1.6$ & $\begin{array}{c}\mathrm{a} \\
5.72 \pm 0.7\end{array}$ \\
\hline 2 & $3.85 \pm 0.6$ & $3.11 \pm 1$ & $4.58 \pm 0.5$ & $1.06 \pm 0.2$ & $7.39 \pm 1.5$ & $11.07 \pm 1.2$ & $\begin{array}{c}\mathrm{b} \\
5.5 \pm 0.53\end{array}$ \\
\hline 3 & $3.8 \pm 1$ & $3.07 \pm 1.2$ & $4.45 \pm 2.2$ & $0.89 \pm 0.3$ & $8.29 \pm 2.1$ & $13.62 \pm 4.6$ & $\begin{array}{c}\mathrm{b} \\
4.02 \pm 0.32\end{array}$ \\
\hline 4 & $3.42 \pm 0.6$ & $2.65 \pm 0.5$ & $4.46 \pm 0.8$ & $0.91 \pm 0.3$ & $7.92 \pm 1.3$ & $12.7 \pm 1.19$ & $\begin{array}{c}\mathrm{b} \\
4.23 \pm 0.25\end{array}$ \\
\hline 5 & $3.53 \pm 0.4$ & $2.59 \pm 0.9$ & $4.94 \pm 0.3$ & $0.82 \pm 0.2$ & $8.28 \pm 1.2$ & $12.51 \pm 0.1$ & $\begin{array}{c}\mathrm{a} \\
6.32 \pm 0.68\end{array}$ \\
\hline
\end{tabular}

Means followed by the same superscripts do not differ significantly $(\mathrm{P}<0.05)$.

\section{Camel milk components of traditional system (\%) as influenced by parity}

Parity had significant effect $(\mathrm{P}>0.05)$ on camel milk components that were collected from intensive management system (Table 2). Wherein proteins, lactose, free fatty acid (FFA) and solid not fat (SNF) were markedly affected by parity.Protein content in $2^{\text {nd }}$ parity recorded highly significant differences $(\mathrm{P}<0.01)$ when compared to $5^{\text {th }}$ one.Our study results are not in agreement with the finding of [36] who reported that parity had significant effects on daily composition of protein and milk protein was significantly higher in parity 3 , as compared to other parities. Moreover, lactose content in $3^{\text {rd }}$ parity recorded significantly $(\mathrm{P}<0.01)$ more values when compared with $5^{\text {th }}$ parity.The findings for lactose in our study are well in the range of $5.0 \%$ by [21], $4.88 \%$ by [27], $5.43 \%$ by [20], $4.21 \%$ by [26], $4.6 \%$ by [34], $5.8 \%$ by [13], $4.4 \%$ by [32], $4.59-5.33 \%$ by [22], $5.61 \%$ by [2], $5.24 \%$ by [16], $4.16 \%$ by [14], $4.47 \%$ by [15] $4.6 \%$ by [24], $4.81 \%$ by [17], $4.1 \%$ by
[23], $4.4 \%$ by [11] and $4.67 \%$ by [36]. While, The findings of the following studies are reported with the lower lactose contents than our study i.e. $3.36 \%$ by [8], $3.9 \%$ by [6], $3.4 \%$ by [22], $3.30 \%$ by [18], $3.4 \%$ by [10] and $3.8 \%$ by [29]. Similarly to protein, SNF content in $2^{\text {nd }}$ parity recorded highly significant differences $(\mathrm{P}<0.01)$ when compared to $5^{\text {th }}$ one.This result is similar to those found by [30].Free fatty acids in $2^{\text {nd }}$ parity recorded highly significant differences values among other parities. Meanwhile, fat content in first and second parities were distinguished with high mean values among other successive parities.This finding is agreed with the findings of [36] who mentioned that the effect of parity on fat content of camel milk was statistically significant. While the other scientists reported that the number of lactation (parity) had no effect on fat [5]; [4]. It noticeable that, most of camel milk samples collected in $5^{\text {th }}$ parity under traditional management system recorded the lowest values among other parities.

Table 2: Camel milk components of traditional system $(\%)$ as influenced by parity

\begin{tabular}{|c|c|c|c|c|c|c|c|}
\hline Parity number & Fats & Proteins & Lactose & FFA & SNF & TS & Acidity \\
\hline \multirow{2}{*}{1} & & $\mathrm{ab}$ & $\mathrm{ab}$ & $\mathrm{b}$ & $\mathrm{ab}$ & & \\
& $3.35 \pm 0.95$ & $2.56 \pm 0.42$ & $4.63 \pm 0.6$ & $0.79 \pm 0.25$ & $7.15 \pm 1.32$ & $11.32 \pm 1.72$ & $5.78 \pm 0.7$ \\
\hline 2 & & $\mathrm{a}$ & $\mathrm{ab}$ & $\mathrm{a}$ & $\mathrm{a}$ & & \\
& $3.5 \pm 0.7$ & $3.03 \pm 0.70$ & $4.47 \pm 0.87$ & $0.99 \pm 0.25$ & $8.13 \pm 0.99$ & $12.36 \pm 2.80$ & $5.9 \pm 0.53$ \\
\hline 3 & & $\mathrm{ab}$ & $\mathrm{a}$ & $\mathrm{b}$ & $\mathrm{ab}$ & & \\
\hline
\end{tabular}

Volume 6 Issue 12, December 2017 


\section{International Journal of Science and Research (IJSR) \\ ISSN (Online): 2319-7064}

Index Copernicus Value (2016): 79.57 | Impact Factor (2015): 6.391

\begin{tabular}{|c|c|c|c|c|c|c|c|}
\hline & $2.66 \pm 1.1$ & $2.67 \pm 0.53$ & $4.74 \pm 0.4$ & $0.71 \pm 0.19$ & $3.93 \pm 0.74$ & $10.83 \pm 1.35$ & $5.69 \pm 0.32$ \\
\hline \multirow{2}{*}{4} & & $\mathrm{ab}$ & $\mathrm{ab}$ & $\mathrm{b}$ & $\mathrm{ab}$ & & \\
& $2.19 \pm 0.8$ & $2.6 \pm 0.5$ & $4.39 \pm 0.64$ & $0.71 \pm 0.8$ & $7.63 \pm 1.18$ & $10.8 \pm 0.5$ & $5.29 \pm 0.25$ \\
\hline \multirow{2}{*}{5} & & $\mathrm{~b}$ & $\mathrm{~b}$ & $\mathrm{~b}$ & $\mathrm{~b}$ & & \multirow{2}{*}{} \\
& $2.83 \pm 1.5$ & $2.32 \pm 0.36$ & $4.01 \pm 0.75$ & $0.72 \pm 0.15$ & $6.89 \pm 1.14$ & $12.51 \pm 0.62$ & $5.32 \pm 0.68$ \\
\hline
\end{tabular}

Means followed by the same superscripts do not differ significantly $(\mathrm{P}<0.05)$.

\section{Camel milk components in two studied systems} (interaction) (\%) as influenced by parities

Primiparous seemed to have no significant effect $(\mathrm{P}>0.05)$ on camel milk components that collected from the two management systems (Table 3). In second parity, protein content in intensive system was markedly affected $(\mathrm{P}>$ 0.05) when compared with that of traditional system. Lactose and acidity of camel milk collected from traditional management system recorded significantly $(\mathrm{P}>0.05)$ more values when compared with that of intensive system.Fat and total solid contents of camel milk samples that were collected from intensive system during $3^{\text {rd }}$ parity recorded high significant differences $(\mathrm{P}<0.05)$ when compared to traditional one. Those results were concordant with [7] who stated that parity seemed to have no effect $(\mathrm{P}<0.05)$ on milk fat content. But disagree with [36] who mentioned that the effect of parity on fat content of camel milk was significant. On the other hand, titratable acidity in $3^{\text {rd }}$ parity of traditional system recorded high significant differences $(P$ $<0.01$ ) in comparison to camel milk samples collected from intensive system. But there were no significantly differences observed in other camel milk components of both intensive and traditional management system in $3^{\text {rd }}$ parity.[35] attributed this to the high temperature or may be due to bacterial activity [25] and [33]. However, variations in $\mathrm{pH}$ and acidity for the same source of milk could be due to differences in hygiene level and the total bacterial count of milk [24].In fourth parity, lactose had an opposite trend in $2^{\text {nd }}$, which significantly $(P>0.05)$ recorded more values in intensive system compared with that of traditional management system (Table 4).Similarly to fourth parity, lactose content in fifth parity, significantly $(\mathrm{P}>0.05)$ recorded more values in intensive system compared with that of traditional management system. But there were no significantly differences observed in other camel milk components of both intensive and traditional management system in $5^{\text {th }}$ parity (Table 5). This may be attributed to sufficient nutrient supplementation and limitation of animal health care in intensive system as reported by [32]. Or maybe attributed to the daily exercise of camels and continuous mobility for grazing as supported by [28].

Table 3: Camel milk components in two studied systems (\%) as influenced by first and second parities

\begin{tabular}{|c|c|c|c|c|c|}
\hline Parity & Components & System & N0 & Mean \pm SD & Sig \\
\hline 1 & Fat & Intensive & 12 & $3.47 \pm 1.2$ & NS \\
\hline & & Traditional & 4 & $3.16 \pm 0.5$ & NS \\
\hline & Protein & Intensive & 12 & $2.73 \pm 0.7$ & NS \\
\hline & & Traditional & 4 & $2.50 \pm 0.2$ & NS \\
\hline & Lactose & Intensive & 12 & $4.56 \pm 0.7$ & NS \\
\hline & & Traditional & 4 & $5.05 \pm 0.4$ & NS \\
\hline & SNF & Intensive & 12 & $8 \pm 1.4$ & NS \\
\hline & & Traditional & 4 & $6.79 \pm 1.8$ & NS \\
\hline & TS & Intensive & 12 & $11.9 \pm 1.5$ & NS \\
\hline & & Traditional & 4 & $10.89 \pm 0.5$ & NS \\
\hline & Acidity & Intensive & 12 & $5.58 \pm 1.2$ & NS \\
\hline & & Traditional & 4 & $6.39 \pm 0.5$ & NS \\
\hline
\end{tabular}

\begin{tabular}{|c|c|c|c|c|c|}
\hline & FFA & Intensive & 12 & $0.93 \pm 0.22$ & NS \\
\hline & & Traditional & 4 & $0.75 \pm 0.39$ & NS \\
\hline 2 & Fat & Intensive & 13 & $4.05 \pm 2$ & NS \\
\hline & & Traditional & 4 & $2.39 \pm 1.2$ & NS \\
\hline & Protein & Intensive & 13 & $3.23 \pm 0.9$ & $*$ \\
\hline & & Traditional & 4 & $2.54 \pm 0.06$ & \\
\hline & Lactose & Intensive & 13 & $4.34 \pm 0.74$ & \\
\hline & & Traditional & 4 & $5.11 \pm 0.2$ & $*$ \\
\hline & SNF & Intensive & 13 & $7.63 \pm 1.41$ & NS \\
\hline & & Traditional & 4 & $8.29 \pm 0.07$ & NS \\
\hline & TS & Intensive & 13 & $12.02 \pm 2.35$ & NS \\
\hline & & Traditional & 4 & $10.92 \pm 1.88$ & NS \\
\hline & Acidity & Intensive & 13 & $4.27 \pm 1.68$ & \\
\hline & & Traditional & 4 & $6.32 \pm 0.71$ & $*$ \\
\hline & FFA & Intensive & 13 & $1.01 \pm 0.22$ & NS \\
\hline & & Traditional & 4 & $1.06 \pm 0.26$ & NS \\
\hline
\end{tabular}

NS: No significant differences; No: number of observation Sig: significance*significant differences at $\mathrm{P} \leq 0.05$;** significant differences at $\mathrm{P} \leq 0.01$

Table 4: Camel milk components in two studied systems (interaction) (\%) as influenced by third and fourth parities:

\begin{tabular}{|c|c|c|c|c|c|}
\hline Parity & Components & System & N0 & Mean \pm SD & Sig \\
\hline 3 & Fat & Intensive & 6 & $3.84 \pm 0.8$ & $*$ \\
\hline & & Traditional & 11 & $2.84 \pm 1.4$ & \\
\hline & Protein & Intensive & 6 & $3.38 \pm 1.28$ & NS \\
\hline & & Traditional & 11 & $2.58 \pm 0.52$ & NS \\
\hline & Lactose & Intensive & 6 & $4.96 \pm 2.43$ & NS \\
\hline & & Traditional & 11 & $4.41 \pm 0.82$ & NS \\
\hline & SNF & Intensive & 6 & $9.23 \pm 1.48$ & NS \\
\hline & & Traditional & 11 & $7.49 \pm 1.19$ & NS \\
\hline & TS & Intensive & 6 & $14.1 \pm 5.39$ & $*$ \\
\hline & Acidity & Traditional & 11 & $11.1 \pm 1.35$ & \\
\hline & & Traditional & 11 & $5.56 \pm 0.41$ & $*$ \\
\hline & FFA & Intensive & 6 & $0.887 \pm 0.33$ & NS \\
\hline & & Traditional & 11 & $0.750 \pm 0.195$ & NS \\
\hline & Fat & Intensive & 4 & $3.25 \pm 0.74$ & NS \\
\hline & & Traditional & 13 & $2.62 \pm 0.96$ & NS \\
\hline & Protein & Intensive & 4 & $2.59 \pm 0.37$ & NS \\
\hline & & Traditional & 13 & $2.64 \pm 0.51$ & NS \\
\hline & Lactose & Intensive & 4 & $4.5 \pm 0.35$ & $*$ \\
\hline & & Traditional & 13 & $4.4 \pm 0.78$ & \\
\hline & SNF & Intensive & 4 & $8.18 \pm 1.41$ & NS \\
\hline & & Traditional & 13 & $7.65 \pm 1.21$ & NS \\
\hline & TS & Intensive & 4 & $11.47 \pm 1.45$ & NS \\
\hline & & Traditional & 13 & $11.36 \pm 1.38$ & NS \\
\hline & Acidity & Intensive & 4 & $3.54 \pm 1.13$ & \\
\hline & & Traditional & 13 & $5.18 \pm 0.65$ & $*$ \\
\hline & & Intensive & 4 & $0.67 \pm 0.09$ & NS \\
\hline & Traditional & 13 & $0.85 \pm 0.27$ & NS \\
\hline & & & $3.7 \pm 1.8$ & \\
\hline & & & & \\
& & & &
\end{tabular}

NS: No significant differences; No: number of observation; Sig: significance*significant differences at $\mathrm{P} \leq 0.05$;** significant differences at $\mathrm{P} \leq 0.01$

\section{Volume 6 Issue 12, December 2017




\section{International Journal of Science and Research (IJSR) \\ ISSN (Online): 2319-7064}

Index Copernicus Value (2016): 79.57 | Impact Factor (2015): 6.391

Table 5: Camel milk components in studied systems (\%) as influenced by fifth parity

\begin{tabular}{|c|c|c|c|c|c|}
\hline Parity & Components & System & N0 & Mean \pm SD & Sig \\
\hline 5 & Fat & Intensive & 4 & $3.61 \pm 0.52$ & NS \\
\hline & & Traditional & 13 & $2.77 \pm 0.89$ & NS \\
\hline & Protein & Intensive & 4 & $1.87 \pm 0.11$ & NS \\
\hline & & Traditional & 13 & $2.63 \pm 0.64$ & NS \\
\hline & Lactose & Intensive & 4 & $4.78 \pm 0.02$ & $*$ \\
\hline & & Traditional & 13 & $3.35 \pm 0.83$ & \\
\hline & SNF & Intensive & 4 & $7.41 \pm 0.57$ & NS \\
\hline & & Traditional & 13 & $7.59 \pm 1.52$ & NS \\
\hline & TS & Intensive & 4 & $12.88 \pm 0.13$ & NS \\
\hline & & Traditional & 13 & $11.55 \pm 1.2$ & NS \\
\hline & Acidity & Intensive & 4 & $7.16 \pm 0.31$ & NS \\
\hline & & Traditional & 13 & $5.36 \pm 0.63$ & NS \\
\hline & FFA & Intensive & 4 & $0.68 \pm 0.23$ & NS \\
\hline & & Traditional & 13 & $0.796 \pm 0.17$ & NS \\
\hline
\end{tabular}

[1] Agab, H. (1993). Epidemiology of Camel Diseases in Eastern Sudan with Emphasis on Brucellosis. M.V.Sc. Thesis. University of Khartoum. PP. 172.

[2] Ahmed, M.M. 1989. The composition and nutritional quality of camel's milk in UAE. In:

[3] Ali, M.S. and Majid, A.A. (2006). Productive and reproductive characters of camels raised in Butana area in eastern Sudan. Proceedings of the International Scientific Conference on camels. 10 - 12 May, 2006. Qassim, Saudi Arabia. pp. 2339 - 2348.

[4] Al-Shaikh, M.A. and M.S. Salah. 1994. Effect of milking interval on secretion rate and composition of camel milk in late lactation. J. Dairy Res. 61:451 -456.

[5] Al-Sultan, S.I. and A.M. Mohammed. 2007. The effects of the number of lactations on the chemical composition of camel milk. J. Camel Pract. and Res. 14(1):61-63.

[6] Bahay, C.M. 1962. Normal contents of Egyptian Camel milk. Vet. Med. J. 8:7-17.

[7] Bakheit, S. A., A. M. Majid and A. M. Abu-Nikhila. 2008. Camels (Camelus dromedarius) under pastoral systems in North Kordofan, Sudan: Seasonal and parity effects on milk composition. J. Camelid Sci. 1:32-36.

[8] Barthe, L. 1950. Fundamentals of dairy chemistry. J. Pharm. Clin. 21:386-394.

[9] Bekele, T., M. Zeleke and R.M.T. Baars. 2002. Milk production performance of the one humped camel (Camelus dromedarius) under pastoral management in semi-arid eastern Ethiopia. Livestock Prod. Sci. 76:3744.

[10] Bengoumi, M., M.G. Vias and B. Faye. 2005b. Camel milk production and transformation in Sub-Saharan Africa in: Dessertification combat and food safety. B. Faye and P. Esenov (Ed). IOS. Press. pp:200-208.

[11] Bhakat, C. and M.S. Sahani. 2006. Au n i q u e s p e ci e $\mathrm{s}$ i $\mathrm{n}$ h ot ar i d de s e r t e co s yste m. Eve r yma n's Sci en ce.X L(6 ): 4 26-429.

[12] Dal Dairy Factory (DDF), Khartoum-North, Sudan.

[13]El- Agamy. 1983. Studies on camels' milk. MSc thesis. Alexandria University, Alexandria, Egypt.

[14]El- Amin, F.M. and C.J. Wilcox. 1992. Milk Composition of Majaheim Camels. J. Dairy

[15]Farag, S.I. and K.M.K. Kebary. 1992. Chemical composition and physical properties if camel's milk and milk fat. In: Proce. 5th Egyptian Conf. of dairy Sci. and Technology, Egypt. pp:57-67.
NS: No significant differences; No: number of observation; Sig: significance*significant differences at $\mathrm{P} \leq 0.05$;** significant differences at $\mathrm{P} \leq 0.01$

\section{Conclusion}

The present study showed variations in camel milk components as affected by parity order under traditional and intensive management systems. Camel milk samples obtained from the intensive system (Tumbool Camel Research Center) and traditional system system (Butana area) revealed highly significant variations between these systems in values of protein, lactose, Fat, total solid contents and acidity

\section{References}

[16]Farah, Z. and M.W. Ruegg. 1989. The size distribution of casein micelles in camel milk. Food Microstruct. 18:211-216.

[17] Guliye, A.Y, R. Yagil, F.D. Deb and Hovell. 2000. Milk composition of Bedouin camels under semi-nomadic production system. J. Camel Pract. and Res. 7(2):209212.

[18]Hjort, A. and G. Dahl. 1984. A note on the camels of the Amar'ar Beja. . In:The Camelid; an all purpose animal, W. Ross Cockrill (Ed.). Vol. I, Proc. Khartoum workshop on Camels, Dec 18-20. 1979. Uppsala, Sweden,. pp:37-50.

[19] http://www.lactoscan.com/products_MCC.html)

[20] Khan, K.U. and T.C. Appanna. 1964. Electrolytes in camel milk. Indian J. Physiol. Allied Sci. 18:129-133.

[21] Kheraskov, K.H. 1953. Camel milk and its products. Konevodstvo. 23:35-37.

[22] Knoess, K.H. 1976. Assignment report on camel production in the middle Awash valley, Project ETH/75/001 Class W/K 3651, FAO, Rome, Italy.

[23] Kouniba, A., M. Berrada, M. Zahar and M. Bengoumi. 2005. Composition and heat stability of Moroccan Camel milk. J. Camel Pract. and Res. 12(2):105-110.

[24] Mehaia, M.A. 1994. Vitamin C and riboflavin content in camels milk: effects of heat treatments. Food Chemistry. 50:153-155.

[25] Mohamed, I.E.M., El Owni, O.A.O., Mohamed, G.E. 1999. Effect of mastitis on milk quality of Friesian cows in Khartoum State. Indian Journal of Animal Sciences, 69: 733- 735 .

[26] Mukasa-Mugerwa, E. 1981. The camel (Camelus dromedarius): a bibliographical review. ILCAMonograph Vol. 5. ILCA, Addis Ababa, Ethiopia. pp: 147.

[27] Ohri, S.P. and B.K. Joshi. 1961. Composition of camel milk. Indian Vet. J. 38:604-606.

[28] Parraguez VH, Thenot M, Latorre E, Ferrando G, Raggi LA (2003) Milk composition in alpaca (Lama pacos): comparative study in two regions of Chile. Arch Zootec 52: 431 439. Proce. vol.1: papers presented in Arabic. vol.2: papers presented in English; Sub-Regional Seminar on Organization and Management of Food Control Laboratories /

[29] Raghvendar, S., A.K. Rai and M.S. Sahani. 2003. The performance capabilities of camels in arid and semi-arid regions of India. Draught Animal News. No. 38. Centre 


\section{International Journal of Science and Research (IJSR) \\ ISSN (Online): 2319-7064}

Index Copernicus Value (2016): 79.57 | Impact Factor (2015): 6.391

for Tropical Veterinary Medicine, University of Edinburgh, Scotland, UK.

[30] Riyadh SA, Faris FA, Elsayed I, Mohammad AA, Ahmad S Moez A (2012) Effect of production system, breed, parity and stage of lactation on milk composition of dromedary camels in Saudi Arabia. J Anim Vet Adv 11: $141-147$.

[31] Saint-Martin, G.; Delmet, C.; Zubeir, A. R. Y.; Peyre, de Fabriques, B.; Harbi, M. S. M. A.; Bagadi, H. O.(1992). Camel Project of Butana : Final Report. Maison Alfort, France, IEMVT. pp. 128.

[32] Sawaya,. W.N., J.K. Khalil, A. Al-Shalhat and H. AlMohammad. 1984. Chemical Composition and Nutritional Quality of Camel Milk. J. Food Sci. 49 (3):744-747.Sci.75:3155-3157.El-

[33] Simon, M., Hasen, A.P. 2001. Effect of dairy packing materials on the shelf life and flavor of ultra pasteurized milk. Journal of Dairy Science, 84:784- 791.

[34] Yagil, R. and Z. Etzion. 1983. Lactation in drought areas: inShual. Development in Ecological and Environmental quality. 11:22-30.

[35] Yagil, R., and Etzion, Z. (1980). Effect of drought condition on the quality of camel milk. Journal Dairy Res. 47:159-166.

[36]Zeleke. M. 2007. Non-genetic factors affecting milk yield and milk composition of traditionally managed camels (Camelus dromedarius) in Eastern Ethiopia. 